\title{
Introduction
}

\section{SANCTUARY IN CONTEXT}

\author{
Randy Lippert and Sean RehaAg
}

I $\mathrm{n}$ recent times, international migrants living without legal status in Canada, the United States, and European countries have resorted to various institutional manifestations of "sanctuary" to resist deportation. Beginning in the early 1980s, the ancient tradition of church sanctuary underwent a revival, with Christian churches providing sanctuary to migrants facing imminent arrest and deportation. These sanctuary practices arose amidst a dramatic increase in the number of asylum seekers arriving in the West and a simultaneous escalation in national and international efforts to discourage and control their arrival through myriad means, including deportation. Since reappearing in the 1980s, sanctuary has shown signs of mutating and moving beyond Christian churches to other faith-based communities and to secular institutions such as universities and cities.

Until recently sanctuary scholarship has focused primarily on sanctuary activity in the US where it emerged as a faith-based social movement in the 1980s. This complex movement spawned a considerable multidisciplinary body of scholarship. Such scholarship ranged from major ethnographic inquiries invoking social movement theory, to thoughtful theological reflections, to sociological questions about deviant behaviour, to careful consideration of legal questions surrounding constitutional freedom-of- religion claims in the wake of US state authorities charging and convicting providers for their sanctuary activities. By the early 1990s sanctuary as a social movement had all but expired in the US context but through their efforts, scholars had effectively exposed sanctuary not only as a substantive realm of interest in its own right but also as a set of practices in which to ground and pursue long-standing questions stemming from diverse disciplines and theories. Yet, despite this rich body of published work, broader inquiries into sanctuary that reach across and beyond US borders are warranted given that sanctuary has occurred outside the US, persisted after the early 1990s, and taken new institutional forms. Situating sanctuary in this broader context provides further opportunity to explore vital questions in social, legal, and political theory pertaining to migration and citizenship processes, civil disobedience, and church-state relations. Opportunities abound to explore these questions both from relatively traditional disciplines and through more contemporary research on social movements, governmental rationality, and identity influenced by the "linguistic turn" in social theory. While studies representing this broader perspective on sanctuary have been undertaken independently, until now a forum in which they can be considered and debated collectively has been lacking.

Accordingly, this special issue of Refuge illuminates sanctuary practices and the theoretical insights to which they give rise in fresh contexts and retrospectively returns to previously studied contexts to re-examine how sanctuary has mutated or spawned unanticipated effects. Assembled are five articles by international scholars that address central theoretical issues from social movement, governmentality, and socio-legal perspectives. The five articles are based on new research on sanctuary in Canada, the US, Finland, and France. These are followed by two succinct reports representing current perspectives and positions of key church sanctuary providers in Canada and Germany. This special issue reveals the continued multidisciplinary nature of sanctuary scholarship, with articles authored by a legal scholar, anthropologists, political scientists, and sociologists as well as contributions from faith-based activists intimately involved in sanctuary provision.

Given that the sanctuary movement in the US is by far the most studied and well-known instance of sanctuary activity in a national context, and because of the nascent New Sanctuary Movement's sudden appearance there in 2007, it is most appropriate to open this issue with an article that recasts an understanding of the nature and significance

(C) Randy Lippert and Sean Rehaag, 2009. This open-access work is licensed under a Creative Commons Attribution-NonCommercial 4.0 International License, which permits use, reproduction and distribution in any medium for non-commercial purposes, provided the original author(s) are credited and the original publication in Refuge: Canada's Journal on Refugees is cited. 
of that original movement many years after its cessation. In their article "Legacies and Origins of the 1980s US-Central American Sanctuary Movement," Hector Perla and Susan Coutin provide a retrospective exploration of the sanctuary movement. Their insightful take on its origins and effects is hinted at in their use of "US-Central American Sanctuary Movement" to refer to the movement in the article's title. The authors argue that the movement's structure and effects were transnational rather than national in character. In particular, the authors suggest that the sanctuary movement arose consonant with the broader activities of Central Americans that sought to encourage North Americans to support social justice activists, particularly in El Salvador. This rethinking of the movement's origins also reveals several significant unintended consequences of sanctuary practices that include legal and policy changes in the US, the increase of remittances to Central America, the growth of the Central American community in the US, and the emergence of new civil society networks in Central and North American countries. These consequences cast doubt on the efficacy of social movement theories that centre on instrumental (i.e., intentional) action. Moreover, as is also exemplified in the recent Canadian context that is more closely tethered to refugee determination and immigration processes, these unanticipated consequences point to the need to accept the particularity of sanctuary activity.

Next, offering a rare glimpse of sanctuary activity in a European country with restrictive immigration policies is Miikka Pyykkönen's article, "Deportation vs. Sanctuary: The Rationalities, Technologies, and Subjects of Finnish Sanctuary Practices." In this article, sanctuary is shown to have been officially sanctioned in its "exposure" form by the Finnish Evangelist Lutheran Church, Finland's major Christian denomination, only in 2007. Drawing on theories of governmentality influenced by Michel Foucault's later writings and lectures and in particular his compelling concept of pastoral power, Pyykkönen considers the 2007 sanctuary incident involving Naze Aghai. Through this analysis, the author argues there are two "pastorates" brought to bear on Naze Aghai and the subjectivities of other immigrants and asylum seekers in Finland. One pastorate comprises state apparatuses aimed at ensuring the well-being of the Finnish population. Another comprises the Church, parish workers, secular activists, and communities, which seeks the vitality and well-being of a broader "flock" that reaches beyond Finland's territorial borders.

In "Lasile religieux, entre lecture libérale et républicaine: quels défis pour les sociétés démocratiques?" Caroline Patsias and Louis Vaillancourt consider sanctuary activity in Canada, France, and the US as a form of civil disobedience. The authors argue that civil disobedience of this sort possesses a complex relation with contemporary conceptions of democracy. Specifically, they contend that how one understands sanctuary's legitimacy partially hinges on whether one adopts a liberal or republican view of democracy.

Continuing with the theme of civil disobedience, Sean Rehaag's article, "Bordering on Legality: Canadian Church Sanctuary and the Rule of Law," argues that when faithbased communities develop formal screening mechanisms to decide who among those requesting sanctuary should receive it, they apply legal norms and procedures akin to those of Canada's official refugee determination process. The author asserts that although Canadian sanctuary practices are typically criticized as a form of civil disobedience that calls into question the rule of law, it is also possible to understand sanctuary practices as a means through which faith-based communities prevent the state from violating both Canadian and international refugee law, thereby actually upholding rule-of-law norms.

In the issue's final feature article, "Wither Sanctuary?," Randy Lippert asks whether sanctuary as an effective resistance strategy is fading away in the Canadian context. The author suggests that sanctuary's recent decline is evinced by a decrease in the number of new sanctuary incidents and an increase in the duration of incidents. He argues that this is not merely a consequence of a tougher stand by the federal Conservatives elected in 2006, arrests of sanctuary recipients, and less exposure via attention from mass media. Rather, sanctuary providers themselves appear to recognize the decreasing success of the tactic and may well be adopting other strategies that include a renewed push to implement the long-promised merit-based appeal for refugee claimants, as well as resorting to "concealment" sanctuary practices.

While the articles in this issue elicit several shared themes, two issues that are particularly evident in the contributions are visibility versus non-visibility and the interrelated question of migrants' agency. Reflected in the earliest sanctuary scholarship, the division between visible and non-visible sanctuary practices is seen in the analytical distinction between sanctuary as "exposure" and sanctuary as "concealment." The former entails a strategy to provide protection to migrants by gaining the attention of mass media, the public, and state authorities by providing sanctuary to migrants in a particular church or religious building. The latter is the antithesis of this effort whereby the provision of sanctuary is purposely concealed from state authorities. This broad theme appears in varied and compelling ways in this issue. In Perla and Coutin's contribution it manifests in relation to questions of agency and whether Central American activists had to stay quiet and become invisible in order to foster North Americans' involvement in the sanctuary movement.

(C) Randy Lippert and Sean Rehaag, 2009. This open-access work is licensed under a Creative Commons Attribution-NonCommercial 4.0 International License, which permits use, reproduction and distribution in any medium for non-commercial purposes, provided the original author(s) are credited and the original publication in Refuge: Canada's Journal on Refugees is cited. 
In other words, invisibility was maintained to hide not only from US authorities but also from other movement activists or would-be participants. In the article by Pyykkönen, it is evident that since 2007 sanctuary in Finland has moved from "concealment" to "exposure." In contrast, in Lippert's account, we see signs that sanctuary in Canada may be moving from "exposure" to "concealment," or perhaps that among current and would-be providers, sanctuary is increasingly obscured by its incorporation into a broader quest for the "Holy Grail": the long-sought merit-based legal appeal. Moreover, this self-limitation of social movement goals to advocacy for changes in refugee determination processes, as important as such developments may be for the well-being of asylum seekers, also highlights the significance of Rehaag's careful consideration of the legal justification for sanctuary in Canada: if sanctuary has a more sound legal basis than usually thought there may yet be greater support for those providing sanctuary through "exposure" rather than letting what has been a successful, highly symbolic, legal strategy continue to wither away.

The other theme concerns questions of migrants' agency. There is little doubt that those at the centre of the incidents play a role in the genesis and cessation of sanctuary activity. These migrants faced with immediate deportation sometimes defy sanctuary's paternalistic currents, whether by deciding to give up sanctuary after long periods or by challenging restrictions imposed by providers. However, it is also true that sanctuary recipients often-even if only temporarily-adopt passive, obedient roles in order to flow with these paternalistic currents or otherwise deem it necessary to "stay quiet." Furthermore, close study of efforts to mobilize the significant legal and financial resources required for gaining legal status through sanctuary and the reality of significant language barriers to mass media access plainly reveal that often migrants are not in a position to come to the forefront of the struggle. To expect otherwise is to deny the grim reality in which they find themselves and to overstate their opportunities for resistance, regardless of how much they are involved in initially requesting sanctuary, bringing it to a close, or escaping its confines altogether. Thus, while questions surrounding how persons at the centre of sanctuary exercise their agency are worthy of further academic exploration, the extent of such agency should not be uncritically overemphasized.

This question of agency also serves as a reminder of the challenges inherent in researching sanctuary. For instance, studying sanctuary as "concealment" is difficult by definition and the ethical and practical problems of studying those in the exceedingly vulnerable position of the sanctuary recipient not only while in sanctuary but afterward are paramount. In fact, few university ethics committees would currently allow these migrants to be included in Canadian federal-grant-funded studies or indeed allow close study of concealment sanctuary at all, due to its questionable legality. As well, it has become clear in work by Lippert as well as Perla and Coutin that even exposure incidents or social movements have elements that remain concealed and that may not become accessible to researchers through informants or other means until long after the fact. Indeed, study long after the fact may be the only means of revealing sanctuary's concealed aspects.

One further challenge for studying sanctuary that this issue highlights is the need for collaborative and comparative work. While most studies in this issue are implicitly comparative (US with Canada, Canada with US, Finland with Canada, and so on), what may be required at this juncture is more systematic comparative work. For example, it would be helpful to know whether the apparently similar (but thus far unelaborated) trajectories in sanctuary tactics in countries such as Canada and Germany can lend insight into why shifts from "exposure" to "concealment" more generally occur. It should be noted that, if Perla and Coutin are correct, comparative scholarship of this kind may well require comparing regional rather than national contexts, but it may also entail comparing different arms of sanctuary activities or comparing independent incidents within countries or regions.

Finally, with the recent advent of the New Sanctuary Movement in the US, the "don't ask, don't tell" effort in Canada, "cities of sanctuary" in the United Kingdom, and ongoing sanctuary incidents in Germany and Finland, and the continuing debates about how to best understand the role of civil disobedience and the rule of law in relation to sanctuary practices, the fruitfulness of sanctuary as a site to reflect on complex theoretical and socio-legal questions suggests further sanctuary scholarship is in order.

\section{Notes}

1. Paul Weller, "Sanctuary as Concealment and Exposure: The Practices of Sanctuary in Britain as Part of the Struggle for Refugee Rights" (paper presented at the conference "The Refugee Crisis: British and Canadian Responses," Keble College and Rhodes House, Oxford, England, 4-7 January 1989).

(C) Randy Lippert and Sean Rehaag, 2009. This open-access work is licensed under a Creative Commons Attribution-NonCommercial 4.0 International License, which permits use, reproduction and distribution in any medium for non-commercial purposes, provided the original author(s) are credited and the original publication in Refuge: Canada's Journal on Refugees is cited. 
Randy Lippert is an associate professor of sociology and criminology in the Department of Sociology, Anthropology, and Criminology at the University of Windsor, Ontario. He obtained a Ph.D. in Sociology from the University of British Columbia (1998) and was previously visiting professor at the Centre of Criminology, University of Toronto (2006). In addition to sanctuary, his research interests include immigration and refugee policies, surveillance practices and urban governance and security arrangements. He recently published the book Sanctuary, Sovereignty, Sacrifice: Canadian Sanctuary Incidents, Power and Law (Vancouver: University of British Columbia Press, 2006) based on intensive empirical research and is currently co-editing a collection called Eyes Everywhere (with David Lyon and Aaron Doyle) on the global growth of camera surveillance.
Sean Rehaag is an assistant professor at the Osgoode Hall Law School at York University, Toronto, Ontario. He is also a resident faculty member at York University's Centre for Refugee Studies. He holds common law and civil law degrees from McGill University (2003) and an S.J.D. from the University of Toronto (2008). His main areas of research include immigration and refugee law, human rights, legal pluralism, and empirical analysis of adjudication. His doctoral dissertation, which received the Alan Marks Medal for best graduate thesis in 2008 at the University of Toronto's Faculty of Law, dealt with the legality of Canadian sanctuary practices.

(C) Randy Lippert and Sean Rehaag, 2009. This open-access work is licensed under a Creative Commons Attribution-NonCommercial 4.0 International License, which permits use, reproduction and distribution in any medium for non-commercial purposes, provided the original author(s) are credited and the original publication in Refuge: Canada's Journal on Refugees is cited. 